\title{
RELEVANSI DLARÛRAH DENGAN RUKHSHAH DALAM PENETAPAN HUKUM SYARA“
}

\author{
Zulbaidah \\ Fakultas Syari'ah dan Hukum UIN Sunan Gunung Djati Bandung \\ Email: zulbaedahz@gmail.com
}

\begin{abstract}
Dlarûrah is the arrival of a grave danger conditions in human beings, which makes him worry about the damage or something that hurts the soul, limbs, mind, wealth and related to it. When it had to do something that is forbidden or required to leave, or to delay its implementation in order to avoid the difficulties that can befall her prediction for not out of the conditions specified by syarak. When that person is allowed to take the law of rukhshah, which is a relief given by God as a legislator to mukallaf either in the form of implementing something that is forbidden or in the form of leaving something that was ordered. As scavengers in urgent situations that when someone does not find food and left fasting in for a sick person. In this case a person may move from the provisions of general law called 'azimah and moved to the legal relief referred rukhshah. Therefore dlarûrah is absolutely related with rukhshah, because dlarûrah is not a law, but left dlarûrah law is a trait that allows mukallaf leave 'azimah and take rukhshah law in which the provisions are measured in accordance with dlarûrah.
\end{abstract}

\begin{abstract}
Abstrak
Dlarûrah adalah datangnya kondisi bahaya yang amat berat pada diri manusia, yang membuat dia khawatir akan terjadi kerusakan, atau sesuatu yang menyakiti jiwa, anggota tubuh, kehormatan, akal, harta dan yang berkaitan dengannya. Ketika itu harus mengerjakan sesuatu yang diharamkan atau meninggalkan yang diwajibkan, atau menunda waktu pelaksanaannya guna menghindari kemadaratan yang diprediksinya dapat menimpa dirinya selama tidak keluar dari syarat-syarat yang ditentukan oleh syara'. Ketika itu seseorang diperbolehkan untuk mengambil hukum rukhshah, yang merupakan keringanan yang diberikan oleh Allah sebagai pembuat hukum kepada mukallaf baik dalam bentuk melaksanakan sesuatu yang dilarang atau dalam bentuk meninggalkan sesuatu yang diperintahkan. Seperti memakan bangkai dalam keadaan terpaksa yang ketika sesorang tidak menemukan makanan yang halal, dan meninggalkan puasa dalam bagi seorang yang sakit. Dalam hal ini seseorang boleh berpindah dari ketentuan hukum yang bersifat umum yang disebut 'azimah, dan berpindah kepada hukum keringanan yang disebut rukhshah. Oleh karena itu dlarûrah erat hubugannya dengan rukhshah, karena dlarûrah bukan merupakan suatu hukum tetapi meninggalkan hukum dlarûrah merupakan suatu sifat yang membolehkan mukallaf meninggalkan 'azimah dan mengambil hukum rukhshah, dengan ketentuan diukur sesuai dengan ukuran dlarûrah-nya.
\end{abstract}

Kata Kunci:

'Azimah, Dlarûrah, Rukhshah, Hukum Syara'

\section{A. Pendahuluan}

Hukum Islam dengan segala seluk-beluknya pada prinsipnya disyariatkan untuk kemaslahatan umum, baik dengan jalan mengambil kemanfaatan maupun dalam bentuk menolak kemadaratan. Oleh karena itu, di dalam menetapkan hukum Islam Allah senantiasa memperhatikan kemudahan dan menjauhkan kesulitan, artinya hukum Islam sejalan dengan fitrah kemanusiaan. 
Islam menjunjung tinggi fitrah kemanusiaan dengan memelihara serta memperhatikan manusia dalam keadaan biasa dan dalam keadaan tertentu, ini berarti bahwa dalam keadaan tertentu Allah tidak memaksa manusia untuk tetap berpegang pada hukum yang bersifat umum ('azimah), akan tetapi Allah membolehkan mengambil hukum pengecualian dengan tujuan untuk memberikan keringanan kepada manusia yang disebut dengan rukhshah.

Hukum Islam yang bersifat umum, artinya bahwa hukum Islam pada mulanya di syariatkan untuk semua mukallaf tanpa memperhatikan keadaan manusia dalam keadaan tertentu. Oleh karena itu didalam pelaksanaanya, sebagian orang merasa berat untuk melaksanakan hukum yang bersifat umum tersebut ('azimah), untuk itu diadakan suatu pengecualian hukum untuk orangorang tertentu yang mempunyai alasan untuk mengambil hukum keringanan (rukhshah).

Rukhshah adalah pembebasan seorang mukallaf dari melakukan tuntutan hukum yang bersifat umum ('azimah) dalam keadaan dlarûrah, baik dalam mengerjakan sesuatu yang terlarang atau meninggalkan sesuatu yang diperintahkan. Namun dalam hal menggunakan hukum rukhshah bagi orang yang telah memenuhi syarat untuk itu terdapat perbedaan pendapat di kalangan ulama.

Jumhur ulama berpendapat bahwa hukum menggunakan rukhshah itu tergantung kepada bentuk uzur yang menyebabkan adanya keringanan itu. Dengan demikian hukum menggunakan rukhshah dapat menjadi wajib seperti memakan bangkai bagi yang tidak mendapatkan makanan yang halal, sedangkan ia khawatir seandainya tidak menggunakan rukhshah akan mencelakakan dirinya.

Zhâhiriyah, Abû Yûsuf, Abû Ishak alSyayrazî dari golongan Syâfi'iyyah dan satu pendapat dari golongan Hanabilah, dan satu riwayat dari Abû Yûsuf dan Imâm al-Syâthibî berpendapat, bahwa hukum rukhshah adalah boleh secara mutlak, karena rukhshah itu hanyalah keringan atau mengangkat kesulitan sehingga mukallaf mempunyai kelapangan dan pilihan antara menggunakan hukum 'azimah dan mengambil hukum rukhshah dalam keadaan terpaksa atau dlarûrah.

Oleh karena itu tulisan ini akan mencoba mengungkap hubungan dlarûrah dengan dalil-dalil rukhshah.

\section{B. Pengertian Dlarûrah}

Secara etimologi dlarûrah adalah dibentuk dari kata al-dlarar (madlarat), yaitu suatu musibah yang tidak dapat dihindari. ${ }^{1}$ Menurut Abû Luwîs al-Ma'lûf mengartikan dlarûrah secara etimologi adalah kebutuhan yang mesti dan dlarûrah disebut dengan kemadaratan. $^{2}$ Secara terminologinya, menurut Muhammad Abû Zahrah kekhawatiran terhadap kehidupan bila tidak melakukan hal yang dilarang atau khawatir hilangnya harta. ${ }^{3}$

Al-Zarkasyî mendefinisikan bahwa dlarûrah adalah sampainya seseorang pada batas dimana jika ia tidak mau memakan yang dilarang maka ia akan binasa, atau mendekati binasa. Seperti seorang yang terpaksa memakan sesuatu yang dilarang dimana jika ia bertahan dalam kelaparannya maka ia akan mati. ${ }^{4}$ Abû Bakar al-Jashash mendefinisikan dlarûrah dengan khawatir terjadi kemadaratan dengan sebab meninggalkan makan baik terhadap jiwa atau sebagian anggota tubuh. ${ }^{5}$

Ulama Syâfi'iyyah mendefinisikan dlarûrah adalah rasa khawatir akan terjadinya kematian atau sakit yang menakutkan atau menjadi semakin parahnya penyakit ataupun membuat semakin lamanya sakit, atau terpisahnya dengan rombongan perjalanan, atau khawatir melemahnya kemampuan berjalan

\footnotetext{
1 Wahbah al-Zuhaylî, al-Dlarûrah al-Syar'iyyah (t.t.: Muassasah al-Risâlah. t.th.), hlm. 65.

2 Ibn Munzhûr al-Ansharî, Lisân al-'Arabî (Kairo: Dâr al-Hadits. 2003), Juz 5, hlm. 155.

3 Muhammad Abû Zahrah, Ushûl Fiqh (Beirut: Dâr al-Fikri al-'Arabî. t.th.), hlm. 45.

4 Wahbah al-Zuhaylî, al-Dlarûrah al-Syar'iyyah. hlm. 66.

5 Abû Bakar al-Jashas, Ahkam al-Qur'ân (Mesir: Isâ al-Bâbî al-Halabî. t.th.), jilid I, hlm. 150.
} 
atau mengedarai kendaraan jika ia tidak makan, dan ia tidak mendapatkan makanan yang halal, dan yang ada hanya makanan yang haram, maka ketika itu ia wajib memakan makan yang haram tersebut. ${ }^{6}$

Definisi yang dikemukakan oleh ulama di atas, Nampak bahwa para ulama hanya berbicara dlarûrah dalam arti sempit yaitu tertuju pada persoalan makanan saja. Dengan demikian Wahbah al-Zuhaylî melihat dlarûrah itu dalam arti umum yaitu suatu prinsip untuk menghalalkan yang haram atau meninggalkan yang wajib, maka ia mendefinisikan dlarûrah dengan: "Datangnya kondisi bahaya yang amat berat pada diri manusia, yang membuat dia khawatir akan terjadi kerusakan, atau sesuatu yang menyakiti jiwa, anggota tubuh, kehormatan, akal, harta dan yang berkaitan dengannya. Ketika itu harus mengerjakan sesuatu yang diharamkan atau meninggalkan nyang diwajibkan, atau menunda waktu pelaksanaannya guna menghindari kemadaratan yang diprediksinya dapat menimpa dirinya selama tidak keluar dari syarat-syarat yang ditentukan oleh syara"'?

Dari beberapa definisi di atas nampak bahwa sebagian ulama mengartikan dlarûrah dalam arti sempit, sedang sebagiannya mengartikan dalam arti luas, oleh karena itu dapat disimpulkan bahwa dlarûrah bukan hanya terbatas pada makanan saja tetapi semua bahaya yang mengancam agama, jiwa, keturunan, akal, dan harta manusia (yang mengancam maqâshid al-Syarî‘ah) yang harus dihindari karena dikhawatirkan akan menimbulkan kemadaratan, karena hal ini mencakup segenap jenis kemadaratan, baik kemadaratan nyang berkaitan dengan makanan, obat, memanfaatkan harta orang lain, memelihara prinsip keseimbangan yang menyangkut akan dalam transaksi, melakukan suatu perbuatan di bawah tekanan terror atau paksaan, yang mendorong manusia kepada apa yang merusak untuk terjerumus ke

6 Ibn Qudamah, al-Mughnî (Kairo: Maktabah alQahiriyyah. 1969), hlm. 306.

Wahbah al-Zuhaylî, al-Dlarûrah al-Syar'iyyah. hlm. 68. dalamnya yang berasal dari diri seseorang, dan ketika itu kemadaratan bias dikatakan pasti atau diprediksi akan terjadi.

\section{Syarat-syarat Dlarûrah}

Dipahami dari definisi di atas, bahwa dlarûrah adalah membolehkan hal dilarang atau meninggalkan yang wajib, tapi hal ini tidak berlaku bebas tetapi ada syarat-syaratnya. Adapun syarat-syarat dlarûrah adalah sebagai berikut :

$$
\text { 1. - ان ان تكون الضرورة قائمة لامنتظرة8 }
$$

Bahwa dlarûrah itu sudah terjadi tidak ditunggu-tunggu.

Artinya kekhawatiran dan kebinasaan akan hilangnya jiwa dan harta benar-benar ada dalam kenyataan. Atau seseorang merasa yakin akan adanya bahaya yang hakiki terhadap lima kebutuhan yang sangat mendasar, yaitu agama, jiwa, kehormatan, akal dan harta, Ketika itu seseorang boleh berpegang pada ketentuan-ketentuan hukum pengecualian guna menghindari bahaya, sekalipun hal itu dapat menimbulkan kerusakan-kerusakan bai orang lain. Hal ini berdasarkan kaidah:

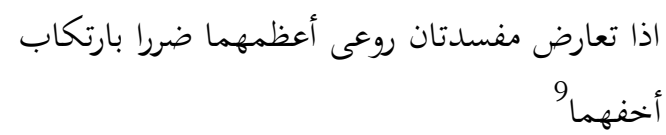

Apabila kita dihadapkan pada dua mafsadat maka diutamakan memperhatikan mana yang lebih besar madharatnya, dengan memilih mengerjakan yang lebih ringan madaratnya.

$$
\text { 2. }
$$

Jelas bahwa orang-orang yang terpaksa dan tidak punya pilihan lain, kecuali melanggar perintah-perintah atau laranganlarang Syara'.

\section{Ibid.}

9 Jalâl al-dîn al- Suyûthî, al-Asybah wa al-Nazhâir (Semarang: Abdul Qadir al-Manur. t.th), hlm. 79. 10 Ibid. hlm. 70. 
Maksudnya tidak ada cara lain yang dibenarkan untuk menghindari kemadaratan selain melanggar hukum. Seperti seorang yang berada disuatu tempat dan dia tidak punya harta sama sekali untuk dimakan, maka untuk menghindari kemadaratan dirinya dia diperbolehkan mengambil makanan orang lain, dan pemilik makanan tersebut harus mengikhlaskannya.

$$
\text { 3. ان تكون الضرورة ملجئسة بحيث يخش تلف النفس عضاء }
$$

Bahwa kemadaratan itu betul-betul memaksa dan khawatir hilang jiwa anggota tubuh.

Jika seseorang dipaksa untuk memakan bangkai dengan ancaman yang mengkhawatirkan hilangnya jiwa atau sebagian anggota tubuhnya sedangkan dihadapannya ada makanan yang halal lagi baik, maka ketika itu dia diperbolehkan memakan sesuatu yang haram. Ulama Syâfi'iyyah dan Hanabilah mengatakan sesuatu yang membolehkan bertayamum maka juga membolehkan memakan sesuatu yang diharamkan.

$$
\text { 4. ألا يخالف المضطر مبادئ الشرعية الا سلا مية }
$$

Bahwa keterpaksaan itu tidak melanggar prinsip-prinsip syariat yang pokok.

Seperti memelihara hak orang lain, menciptakan keadilan, menunaikan amanah, menghindari kemadaratan, diharamkan berzina, membunuh, kufur dan merampas untuk mendapatkan harta.

$$
\text { 5. ان ينتصر فيما يباع يتنوله للضرورة13 }
$$

Bahwa orang yang terpaksa itu membatasi diri pada hal yang dibenarkan melakukannya karena dlarûrah.

Maksudnya melakukan sesuatu yang diharamkan ketika dlarûrah itu ada batasbatasnya.

\footnotetext{
Ibid.

lbid. hlm. 71.
}

3 lbid.
Sedangkan Shobhî Mahmashânî menyebutkan syarat-syarat dlarûrah sebagai berikut :

1. Ada batasan menurut ketentuan nash. maksudnya, kesulitan itu baru boleh dianggap di dalam persoalan yang tidak ada nash-nya;

2. Ada batasan nilai. Artinya, bahwa sesuatu yang diperbolehkan karena dlarûrah harus dinilai dengan ukuran dlarûrahnya, karena dlarûrah adalah suatu pengecualian dari peraturan, sedangkan keadaan yang dikecualikan harus diberi tafsiran yang sempit, dan kelonggaran tersebut tidak boleh berlaku mutlak tetapi harus menurut ukuran yang biasa untuk menghilangkan kesulitan seperti seorang yang kelaparan diperbolehkan mencuri sepotong roti untuk menutupi kelaparannya ketika itu akan tetapi tidak diperbolehkan mencuri sekaleng roti; dan

3. Ada batasan waktu. Keringan hukum karena dlarûrah hanya boleh berlaku selama dalam keadaan dlarûrah, apabila kesulitan itu telah hilang maka jelas keringan itupun berakhir, maka harus kembali kepada hukum yang asal.

Setelah memperhatikan syarat-syarat dlarûrah di atas, maka dapat diketahui bahwa syarat dlarûrah itu adalah:

1. Bahwa Dlarûrah itu harus terjadi;

2. Sudah saatnya mengerjakan dlarûrah tersebut;

3. Ada kekhawatiran hilang jiwa dan anggota tubuh;

4. Tidak melanggar hak orang lain; dan

5. Ada batasnya, baik batasan nilai maupun batasan waktu.

\section{Keadaan Dlarûrah}

Al-Qurthubî berpendapat, bahwa keadaan terpaksa itu tidak terlepas dari dua hal, yaitu karena adanya paksaan dari orang yang menganiaya atau karena lapar pada musim paceklik. ${ }^{14}$ Fakhru al-Râzî mengatakan, dlarûrah itu ada dua sebabnya, karena lapar yang

14 Al-Qurthubî, al-Jamî‘ li Ahkâm al-Qur'ân (t.t.: Dâr al-Kitâb al-'Arabiyyah. t.th.), jilid II, hlm. 225. 
berlebihan dan tidak ada makanan yang halal, dan dipaksa oleh seseorang. ${ }^{15}$ Menurut Ibn 'Arabî, keadaan terpaksa itu bisa terjadi karena adanya paksaan dari seseorang yang menganiaya atau karena kelaparan di musim paceklik atau karena kefakiran dimana seseorang tidak mendapatkan makanan yang halal. ${ }^{16}$ Dengan demikian bagi ulama ini Dlarûrah itu tiga macam, karena paksaaan, kelaparan, dan kefakiran. Sedangkan menurut Wahbah al-Zuhaylî keadaan dlarûrah mencakup semua keringanan bagi manusia dan memiliki banyak keadaan, diantaranya: dlarûrah makanan (lapar dan haus), pengobatan, paksaan, sakit, lupa, bodoh, kesulitan, perjalanan, 'umûm al-balwâ, dan cacat.

Dengan demikian keadaan dlarûrah itu adalah semua keadaan yang membutuhkan suatu keringan hukum (rukhshah) bagi manusia untuk menghindari kemadaratan yang menimpa agama, jiwa keturunan, akal, dan harta.

\section{E. Dalil-dalil Rukhshah}

Rukhshah pada prinsipnya adalah keringanan yang diberikan Allah sebagai pembuat hukum kepada mukallaf dalam suatu keadaan tertentu yang berlaku terhadap mukallaf tersebut. Ada rukhshah dalam bentuk memperbuat, yaitu keringanan untuk melakukan sesuatu perbuatan yang menurut asalnya harus ditinggalkan, Perbuatan yang menurut asalnya terlarang ini disebut dengn 'azimah. Dalam keadaan dlarûrah dan hajat perbuatan yang terlarang itu hukumnya menjadi boleh. Ada rukhshah dalam bentuk meninggalkan, yaitu keringan untuk meninggalkan perbuatan yang menurut hukum 'azimah-nya adalah wajib atau sunnah. Dalam bentuk asalnya hukumnya adalah wajib atau sunnah. Tetapi dalam keadaan tertentu mukallaf tidak dapat melakukannya, karena kalau dilakukannya akan membayakan pada dirinya, dalam hal ini diperbolehkan meninggalkannya.

15 Fakhru al-Razî, Tafsîr al-Kabîr (Taheran: Dâr alKitâb al-'Amaliyyah. t.th.), Jilid V, hlm. 207.

16 Ibn al-‘Arabî, Ahkam al-Qur'ân. hlm. 55.
Adapun dalil-dalil yang diterapkan di dalam al-Quran, diantaranya adalah:

1. QS. al-Baqarah ayat 173 yang berbunyai:

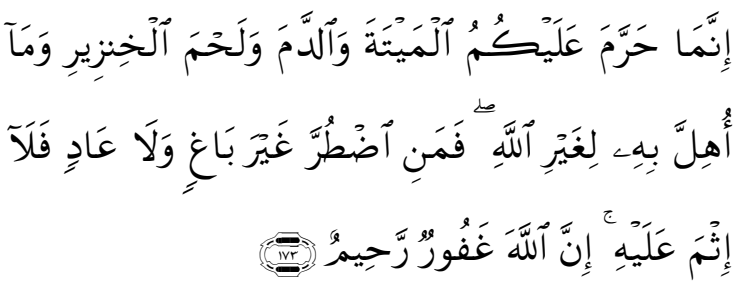

Sesungguhnya Allah hanya mengharamkan bagimu bangkai, darah, daging babi, dan binatang yang (ketika disembelih) disebut (nama) selain Allah, tetapi barangsiapa dalam keadaan terpaksa (memakannya) sedang dia tidak menginginkannya dan tidak (pula) melampaui batas, Maka tidak ada dosa baginya. Sesungguhnya Allah Maha Pengampun lagi Maha Penyayang.

Ayat ini menjelaskan bahwa seseorang yang dalam keadaan terpaksa atau dlarûrah dibolehkan memakan bangkai, darah, daging babi, dan binatang yang ketika disembelih disebut nama selain Allah, demi untuk memelihara diri dari kebinasaan.

2. QS. al-An'âm ayat 145 yang berbunyi:

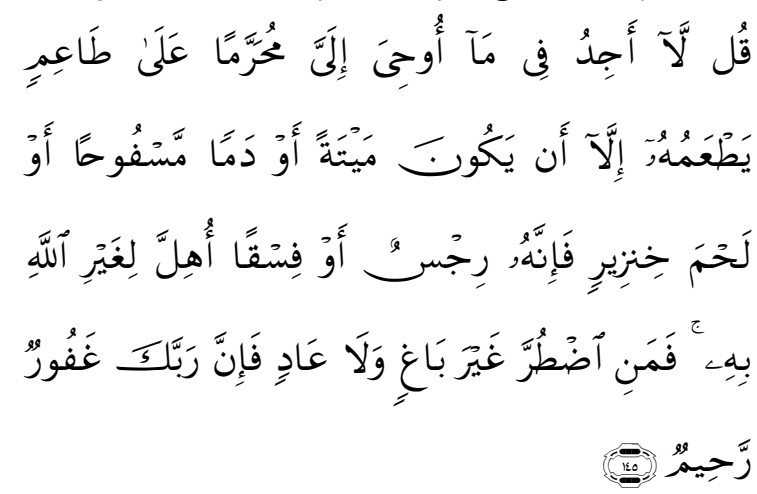

Katakanlah: "Tiadalah Aku peroleh dalam wahyu yang diwahyukan kepadaku, sesuatu yang diharamkan bagi orang yang hendak memakannya, kecuali kalau makanan itu bangkai, atau darah yang mengalir atau daging babi, karena Sesungguhnya semua itu kotor atau binatang yang disembelih atas nama selain Allah. Barangsiapa yang dalam keadaan terpaksa, sedang dia tidak menginginkannya dan tidak (pula) melampaui 
batas, maka sesungguhnya Tuhanmu Maha Pengampun lagi Maha Penyayang.

Ayat ini menjelaskan tentang sesuatu yang diharamkan Allah dan dipebolehkan dalam keadaan terpaksa atau dalam keadaan dlarûrah.

3. QS. al-Nahl ayat 115 yang berbunyi :

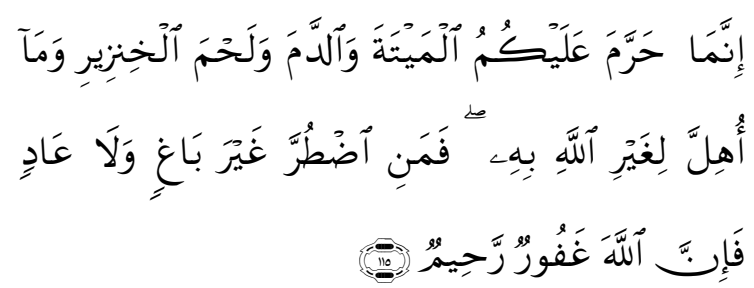

Sesungguhnya Allah hanya mengharamkan atasmu (memakan) bangkai, darah, daging babi dan apa yang disembelih dengan menyebut nama selain Allah; tetapi barangsiapa yang terpaksa memakannya dengan tidak menganiaya dan tidak pula melampaui batas, maka sesungguhnya Allah Maha Pengampun lagi Maha Penyayang.

4. QS. al-An'âm ayat119 yang berbnyi:

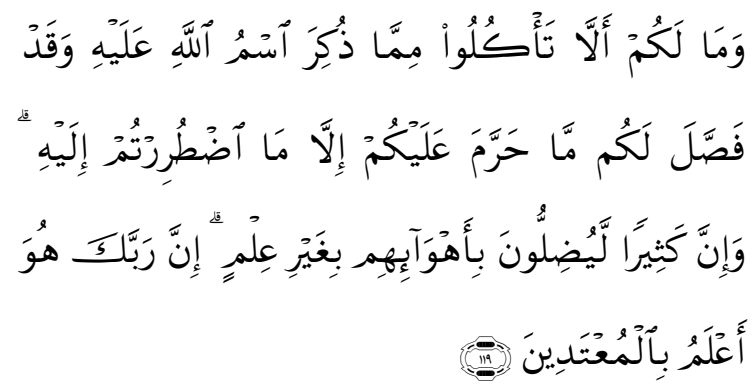

Mengapa kamu tidak mau memakan (binatang-binatang yang halal) yang disebut nama Allah ketika menyembelihnya, padahal sesungguhnya Allah telah menjelaskan kepada kamu apa yang diharamkan-Nya atasmu, kecuali apa yang terpaksa kamu memakannya. dan Sesungguhnya kebanyakan (dari manusia) benar benar hendak menyesatkan (orang lain) dengan hawa nafsu mereka tanpa pengetahuan. Maka sesungguhnya Tuhanmu, Dia-lah yang lebih mengetahui orang-orang yang melampaui batas.
Dengan memperhatikan ayat al-Quran di atas, jelas bahwa Allah memberikan keringanan hukum terhadap orang yang dalam keadaan terpaksa, dengan membolehkan memakan yang ndiharamkan, seperti bangkai, darah, daging babi, dan binatang yang disembelih dengan menyebut nama selain Allah.

Di samping ayat al-Quran di atas, ada beberapa hadits Rasul yang berkaitan dengan keringan hukum dalam keadaan terpaksa atau dlarûrah, diantaranya adalah :

$$
\begin{aligned}
& \text { عن ابى واقد الليش قال : قلت يا رسول الله إنا بأرض }
\end{aligned}
$$

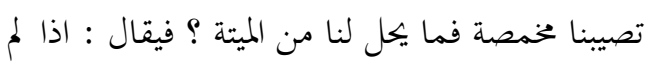

$$
\begin{aligned}
& \text { تصطبحوا ولم تفتبقواولم تحتفؤوابها بقلا فشأنكم بها (رواه } \\
& \text { أحمد). }
\end{aligned}
$$

Dari Abî Wâqid al-Lays dia berkata: Aku bertanya, Ya Rasulallah sesungguhnya kami pada suatu daerah kelaparan (masa paceklik) apakah kami dibolehkan memakan bangkai? Rasulullah menjawab apabila kamu tidak mendapat makan pagi, minuman siang atau tidak mendapatkan makanan dimusim dingin maka dibolehkan bagi kamu hal tersebut. (HR. Ahmad

Dan hadits Rasulullah SAW yang berbunyi :

$$
\text { صن جمابر بن سمرة أن اهل البيت كا نوا بالحرة محتاجين قال }
$$

Dari Jâbir bin Samurah bahwa sesungguhnya Ahlul bait pernah berada disatu musim panas sedang mereka membutuhkan makanan. Jâbir berkata: maka matilah seekor unta milik mereka atau milik yang yang lainnya. Lalu Rasulullah SAW memberikan keringanan kepada

17 Imâm Ahmad ibn Hanbal, Musnad Imâm Ahmad (Beirut: al-Maktab al-Islamî. t.th.), jilid V, hlm. 218. 
mereka untuk memakan unta tersebut. Jabir berkata bahwa mereka terpelihara dari musim dingin yang masih tinggal. (HR. Ahmad)

Berdasarkan ayat dan hadits tersebut jelas bahwa ada suatu keringanan hukum didalam situasi dlarûrah dari yang haram menjadi boleh, Kemudian para mujtahid menyusun kaidah-kaidah fikih yang berkaitan dengan keringan hukum yang berkaitan dengan keringanan hukum dalam keadaan dlarûrah, diantaranya yaitu:

$$
\text { المشقة تجلب التيسر } 18
$$

Kesulitan itu membawa kepada sesuatu kemudahan.

Kemudian kaidah ini dikembangkan oleh mujtahid menjadi kaidah yang berbunyi:

$$
\text { الامر إذا ضاق اتسع }
$$

Suatu perkara apabila sempit menjadi lapang.

Maksudnya setiap kesempitan yang dihadapi oleh seseorang harus diperlonggar, sehingga merasa adanya kemudahan dengan datangnya syariat Islam.

$$
\text { الضرورات تبيح المحظور ات20 }
$$

Dlarûrah-dlarûrah itu membolehkan hal yang dilarang.

Kebolehan mengambil keringanan hukum tersebut hanya sekedar untuk menutupi dlarûrah atau keterpaksaan ketika itu, artinya tidak boleh berlebihan. Sesuai dengan kaidah berikut:

$$
\text { ما ابيح للضرورة يفدر بفدرها }
$$

Sesuatu yang diperbolehkan karena dlarûrah diukur menurut kadar dlarûrahnya.

Artinya kebolehan mengambil hukum keringanan itu hanya sekedar untuk menghilangkan keterpaksaan atau dlarûrah ketika

$$
\begin{array}{ll}
{ }_{19} & \text { Ibid. } \\
20 & \text { Ibid. hlm. } 60 . \\
21 & \text { Ibid. hlm. } 61 .
\end{array}
$$

itu saja tidak boleh memakan makanan yang haram ketika tidak menemukan makanan yang halal terlalu kenyng tetapi hanya sekedar untuk menyelamatkan jiwa saja biar terhindar dari kemadaratan.

\section{F. Hukum Menggunakan Rukhshah dalam Keadaan Dlarûrah.}

Hukum Islam bertujuan untuk mewujudkan kemashlahatan ummat dalam rangka menarik kemanfaatan sebanyak-banyaknya bagi ummat dan menolak kemadaratan sejauh-jauhnya dari ummat. Oleh karena itu, dalam keadaan terpaksa atau dlarûrah diperbolehkan melakukan sesuatu yang dilarang atau meninggalkan sesuatu yang wajib. Hal ini sesuai dengan kaidah fikih yang berbunyi :

$$
\text { الضرورات تبيح المحظور ات22 }
$$

Dlarûrah-dlarûrah itu membolehkan segala yang dilarang.

Kaidah ini muncul setelah para ahli fikih memahami ayat al-Quran dalam surat al-Baqarah ayat 173 yang berbunyi:

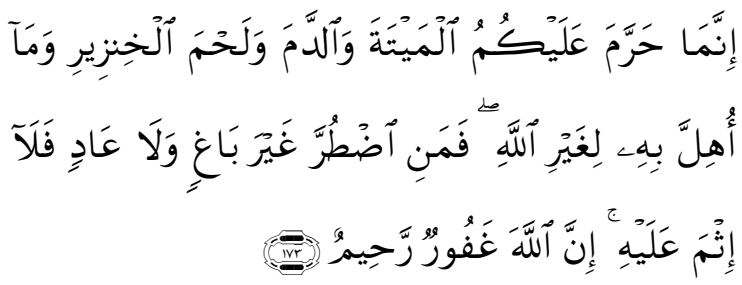

Sesungguhnya Allah Hanya mengharamkan bagimu bangkai, darah, daging babi, dan binatang yang (ketika disembelih) disebut (nama) selain Allah. tetapi barangsiapa dalam keadaan terpaksa (memakannya) sedang dia tidak menginginkannya dan tidak (pula) melampaui batas, maka tidak ada dosa baginya. Sesungguhnya Allah Maha Pengampun lagi Maha Penyayang.

Dalam ayat tersebut dijelaskan bahwa ada beberapa makanan yang diharamkan, yaitu bangkai, darah, daging babi, dan binatang yang disembelih dengan menyebut nama selain Allah, tetapi dalam keadaan ter-

22 Ibid. 
paksa atau dlarûrah diperbolehkan memakan makanan yang diharamkan tersebut.

Zhâhiriyah, Abû Yûsuf, Abû Ishak alSyayrazî dari golongan Syâfi'iyyah dan satu pendapat dari golongan Hanabilah, dan satu riwayat dari Abû Yûsuf, mengatakan bahwa diperbolehkan bagi orang yang dalam keadaan terpaksa atau bagi orang yang dipaksa melakukan sesuatu yang haram, seperti memakan bangkai, darah, daging babi, meminum khamar atau mengambil harta orang lain, maka orang tersebut tidak berdosa. ${ }^{23}$

Alasan yang dipakai oleh kelompok ini, bahwa diperbolehkan mengambil hukum keringan dalam keadaan terpaksa atau dlarûrah adalah:

1. QS. al-An'âm ayat 119:

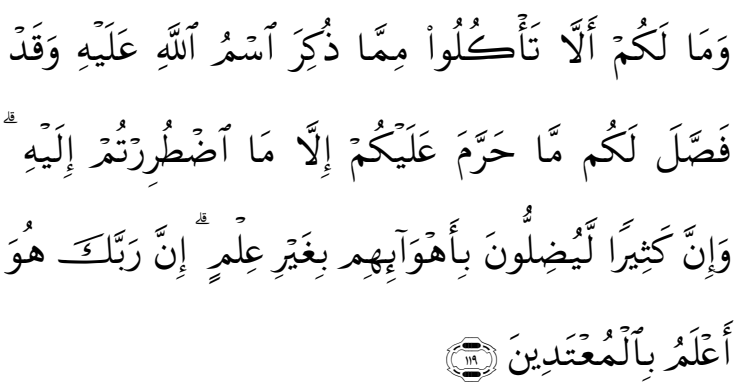

Mengapa kamu tidak mau memakan (binatang-binatang yang halal) yang disebut nama Allah ketika menyembelihnya, padahal sesungguhnya Allah telah menjelaskan kepada kamu apa yang diharamkan-Nya atasmu, kecuali apa yang terpaksa kamu memakannya. Dan sesungguhnya kebanyakan (dari manusia) benar benar hendak menyesatkan (orang lain) dengan hawa nafsu mereka tanpa pengetahuan. Maka Sesungguhnya Tuhanmu, Dia-lah yang lebih mengetahui orang-orang yang melampaui batas.

2. QS. al-Baqarah ayat 173:

23 Wahbah al-Zuhaylî, al-Dlarûrah al-Syar'iyyah. hlm. 289.

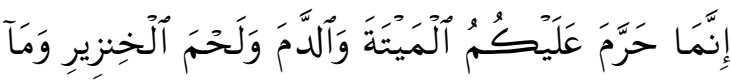

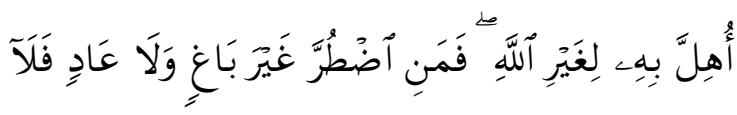

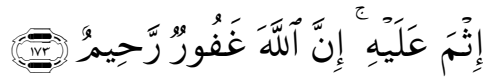

Sesungguhnya Allah hanya mengharamkan bagimu bangkai, darah, daging babi, dan binatang yang (ketika disembelih) disebut (nama) selain Allah tetapi barangsiapa dalam keadaan terpaksa (memakannya) sedang dia tidak menginginkannya dan tidak (pula) melampaui batas, Maka tidak ada dosa baginya. Sesungguhnya Allah Maha Pengampun lagi Maha Penyayang.

3. QS. al-Mâidah (5) ayat 3:

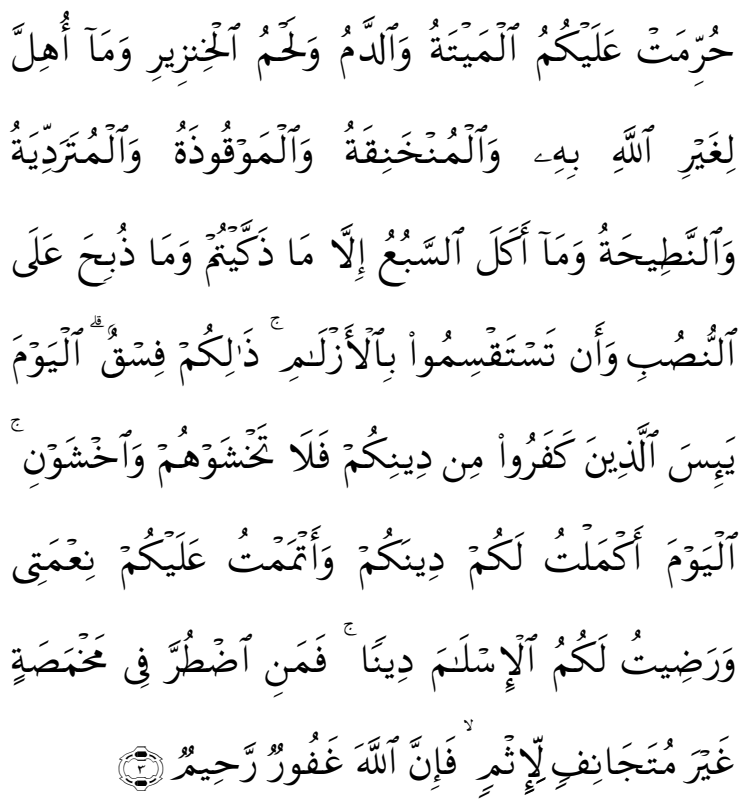

Diharamkan bagimu (memakan) bangkai, darah, daging babi, (daging hewan) yang disembelih atas nama selain Allah, yang tercekik, yang terpukul, yang jatuh, yang ditanduk, dan diterkam binatang buas, kecuali yang sempat kamu menyembelihnya, dan (diharamkan bagimu) yang disembelih untuk berhala. dan (diharamkan juga) mengundi nasib dengan anak panah, (mengundi nasib dengan anak panah itu) adalah kefasikan. pada hari ini orang-orang kafir telah putus asa untuk (mengalahkan) agama- 
mu, sebab itu janganlah kamu takut kepada mereka dan takutlah kepada-Ku. pada hari ini telah Aku sempurnakan untuk kamu agamamu, dan telah Aku cukupkan kepadamu nikmat-Ku, dan telah Ku-ridhai Islam itu jadi agama bagimu. Maka barang siapa terpaksa karena kelaparan tanpa sengaja berbuat dosa, sesungguhnya Allah Maha Pengampun lagi Maha Penyayang.

Berdasarkan ayat tersebut di atas jelas bahwa kelompok ini membolehkan melakukan perbuatan yang terlarang dalam keadaan terpaksa atau dlarûrah, artinya boleh memilih antara melakukan atau tidak. Oleh karena itu bagi seseorang yang enggan atau tidak mau mengambil hukum keringanan dalam keadaan terpaksa, seperti memakan bangkai lalu dia mati (meninggal dunia) maka orang tersebut tidak berdosa. Karena zahir ayat di atas hanya memfaedahkan hukum mubah atau boleh. Hal ini diperkuat oleh Ibn Hazm sebagai berikut:

Bahwa sesuatu yang diperbolehkan melakukannya karena dlarûrah, seperti makan dan minum, dibolehkan juga disebabkan paksaan, karena paksaan itu adalah dlarûrah. Oleh karena itu, barangsiapa yang dipaksa melakukan sesuatu yang haram maka dia tidak berdosa karena di boleh melakukannya. ${ }^{24}$

Pendapat dini juga diperkuat dengan atsar shahabat berikut ini:

Dari 'Abdullah ibn Hudzafah al-Sahmî sahabat Rasulullah SAW: Bahwa tentara Rum menahannya di dalam rumah dan memberinya minum khamar yang dicampur dengan air, dan makanan dari daging babi yang digoreng selama tiga hari, dia tidak mau memakan dan meminumnya, sehingga kepalanya menekur karena sangat lapat dan sangat haus, Mereka punya kekhawatiran tentang keselamatan jiwanya lalu mengeluarkan-

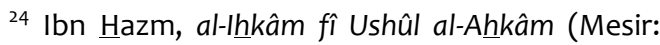
Mathba'ah al-Imâm. t.th.), hlm. 329-330. nya. Lalu 'Abdullah ibn Hudzafah berkata: Ya Allah sebenarnya telah dihalalkan bagiku, karena aku orang yang dalam keadaan terpaksa, dan aku tidak akan mengecewakan-Mu ya Allah dengan agama Islam. ${ }^{25}$

Dengan demikian, menurut pendapat kelompok ini bahwa melakukan perbuatan yang terlarang dalam keadaan terpaksa atau dlarûrah adalah boleh, dimana boleh memilih antara mengambil hukum yang bersifat umum ('azimah) atau mengambil hukum keringanan (rukhshah). Seandainya orang yang dalam keadaan terpaksa itu mati (meninggal dunia) karena tidak melakukan yang haram, seperti memakan sesuatu yang haram karena terpaksa maka orang tersebut tidak berdosa.

Jumhur ulama, diantaranya Hanafiyah, Malikiyah, Syâfi'iyyah, dan Hanabilah, berpendapat bahwa orang yang terpaksa dan yang dipaksa wajib melakukan sesuatu yang diharamkan untuk memelihara jiwanya dari kebinasaan. ${ }^{26}$

Alasan yang dipakai oleh kelompok ini adalah sebagai berikut:

1. QS. al-Baqarah ayat 195:

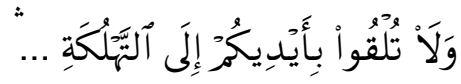

... dan janganlah kamu menjatuhkan dirimu sendiri ke dalam kebinasaan...

2. QS. al-Nisâ' ayat 29:

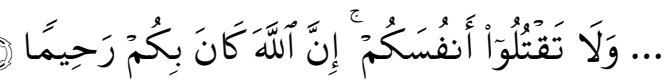

... dan janganlah kamu membunuh dirimu; Sesungguhnya Allah adalah Maha Penyayang kepadamu...

Larangan bunuh diri berarti perintah untuk melindungi kehidupan, menurut pendapat kelompok ini hukumnya adalah wajib memelihara diri dalam keadaan terpaksa, seperti dalam hal memakan makanan yang haram

Ibid. 285 .

26 Wahbah al-Zuhaylî, al-Dlarûrah al-Syar'iyyah. hlm. 286. 
ketika tidak menemukan makanan yang halal, apabila seseorang tidak memakannya dalam keadaan terpaksa tersebut maka orang tersebut berdosa.

Pendapat ini diperkuat dengan keterangan dari ibn Katsir yang menjelaskan bahwa: "Dari Masyruq dia berkata: Siapa yang terpaksa lalu dia tidak makan dan tidak minum kemudian dia mati maka dia masuk neraka. Hal ini menghendaki bahwa memakan bangkai dalam keadaan terpaksa tiu merupakan sesuatu ketentuan yang umum ('azimah) bukan merupakan sesuatu keringan hukum (rukhshah). ${ }^{27}$

Dengan demikian kelompok ini berpendapaat bahwa wajib bagi seseorang yang dalam keadaan terpaksa untuk memakan sesuatu yang haram untuk menyelamatkan dirinya, karena ketika dalam keadaan terpaksa tersebut seseorang bukan mengambil hukum pengecualian atau keringanan tetapi mengambil hukum yang umum. Oleh karena itu bagi orang yang merfasa keberatan untuk memakan sesuatu yang haram dalam keadaan dlarûrah, lalu dia mati maka orang tersebut berdosa.

Jika diperhatikan pendapat para ulama di atas, Nampak bahwa mereka berbeda prinsip di dalam menetapkan hukum tentang melakukan sesuatu yang haram dalam keadaan terpaksa. Sebagaian dari mereka memandang bahwa melakukan perbuatan yang haram dalam keadaan terpaksa adalah merupakan keringan hukum (rukhshah), akan tetapi sebagaian yang lainnya berpendapat bahwa melakukan sesuatu yang haram dalam keadaan terpaksa tersebut merupakan ketentuan umum atau disebut dengan 'azimah.

Dengan memperhatikan alasan yang dipakai oleh kedua pendapat tersebut, Imâm al-Syâthibî berpendapat bahwa hukum mengambil perbuatan yang terlarang dalam keadaan terpaksa atau ruhkshah adalah boleh secara mutlak. Dalam hal ini al-Syâthibî mengemukakan argumentasinya yang menim-

${ }^{27}$ Ibn Katsir, Tafsîr al-Quran al-'Azhîm (Libanon: Dâr al-Fikr. 1984), hlm. 206. bulkan polemik dengan jumhur ulama, Adapun argumentasi yang dikemukakan oleh alSyâthibî adalah sebagai berikut:

Pertama, Melakukan sesuatu yang dilarang dalam keadaan terpaksa itu adalah merupakan keringan hukum yang disebut dengan rukhshah, yang tujuannya adalah untuk mengangkat kesulitan sehingga mukallaf mempunyai kelapangan dan pilihan antara menggunakan hukum 'azimah atau mengambil rukhshah yang hukumnya adalah mubah (boleh). Ketentuan ini sesuai dengan dalil juz'iy (rinci) seperti “ فلا إثم " (tidak berdosa) memakan bangkai, dalam firman Allah dalam surat al-Baqarah ayat 173. Begitu pula ucapan " (tidak ada halangan) meng-qashar shalat bagi musafir dalam firman Allah surat al-Nisâ' ayat 101;

Kedua, Kalau menggunakan rukhshah itu diperintahkan, baik dalam bentuk wajib atau sunnah maka hukumnya akan berubah menjadi 'azimah, karena hukum wajib itu merupakan keharusan pasti yang tidak mengandung pilihan lain. Dengan demikian, berarti menghimpun aturan perintah dan keringanan, namanya menghimpun dua hal yang berlawanan, dan yang demikian adalah mustahil. Oleh karena itu, perintah yang wajib harus dikembalikan kepada hukum asal yaitu 'azimah, maka orang yang dalam keadaan terpaksa yang tidak menemukan makanan yang halal itu diperbolehkan memakan bangkai untuk menolak keterpaksaannya; dan

Ketiga, Larangan bunuh diri yang berarti perintah untuk melindungi kehidupan itu bukan merupakan hukum keringanan atau rukhshah, karena ia kembali kepada prinsip umum yang semula, yaitu 'azimah. Sedangkan seseorang yang dalam keadaan terpaksa yang tidak menemukan makanan yang halal lalu dia memakan sesuatu yang diharamkan itu adalah peralihan dari hukum yang berlaku secara umum kepada hukum yang bersifat keringanan atau rukhshshah. ${ }^{28} \mathrm{a}$

28 Abû Ishaq al-Syathibî, al-Muwâfaqât fî Ushûl al-Syarî́ah (Beirut: Dâr al-Kutub al-'Arabi. 2002), hlm. 34. 
Al-Syâthibî menegaskan, bahwa hukum rukhshah itu adalah ibahah, dan mengataan bahwa masalah ini harus dilihat secara rinci karena perintah untuk memelihara jiwa itu bersifat numum. Tidak ada nash secara pasti mewajibkan memakan bangkai sehingga dia berdosa jika meninggalkannya.

Dengan demikian, melakukan sesuatu yang terlarang dalam keadaan terpaksa atau dipaksa (dlarûrah) adalah peralihan hukum dari 'azimah kepada hukum rukhshah dan hukumnya adalah boleh, artinya boleh memilih antara melakukan sesuatu yang dilarang ketika terpaksa atau meninggalkannya. Seperti seseorang yang sedang dalam keadaan terpaksa yang tidak menemukan makanan yang halal maka ketika itu ia boleh memilih antara memakannya dengan meninggalkannya. Apabila ia meninggalkannya lalu dia mati maka ia tidak berdosa, tetapi diukur dengan kadar dlarûrahnya. Hal ini sesuai dengan kaidah fikih yang berbunyi:

$$
\text { ما جاز للضرورة يقدر بقدرها29 }
$$

Sesuatu yang dibolehkan karena dlarûrah diukur menurut ukuran dlarûrahnya.

Maksudnya, seseorang yang dalam keadaan terpaksa yang tidak menemukan makanan yang halal tidak diperbolehkan memakan makanan yang haram sampai kenyang, tetapi hanya sekedar untuk menutupi kelaparannya ketika itu saja untuk menyelamatkan jiwanya. Sebagaimana yang dijelaskan oleh Muhammad Rasyid Ridlâ: "Bahwa kata “غير باغ" , artinya adalah tidak berusaha untuk mencarinya (mencari makanan yang haram tersebut), dan tidak punya keinginan untuk memakannya karena zatnya. Dan kata " artinya tidak melampaui batas ukuran dlarûrah".30

Oleh karena itu, semakin jelas bahwa dlarûrah itu sangat erat hubungannya dengan rukhshah, bahwa dlarûrah itu hanya sebagai sifat untuk membolehkan seseorang

29 Ibid. hlm. 62.

30 Muhammad Rasyid ridlâ, Tafsîr al-Manâr (Beirut: Dâr al-Ma'rufah. t.th.), hlm. 98. berpindah dari ketentuan hukum yang bersifat umum ('azimah) kepada ketentuan hukum yang bersifat pengcualian atau keringanan (rukhshah). Jadi dlarûrah itu bukan suatu hukum tetapi hukumnya adalah rukhshah.

\section{G. Kesimpulan}

Hukum Islam bertujuan untuk mewujudkan kemashlahatan umat dalam rangka menarik kemanfaatan sebanyak-banyaknya bagi ummat dan menolak kemadaratan sejauhjauhnya dari ummat. Oleh karena itu dalam keadaan terpaksa atau dlarûrah diperbolehkan melakukan sesuatu yang dilarang atau meninggalkan sesuatu yang wajib. Dalam hal ini berpindah dari ketentuan hukum yang bersifat umum ('azimah) kepada pengecualian hukum yang berbentuk keringanan (rukhshah). Dengan demikian, dlarûrah bukan merupakan suatu hukum tetapi hanya merupakan suatu sifat untuk seseorang bisa mengambil hukum keringanan atau rukhshah.

\section{Daftar Pustaka}

Ansharî, Ibn Munzhûr al-. 2003. Lisân al'Arabî. Kairo: Dâr al-Hadits.

Hanbal, Imâm Ahmad ibn. Musnad Imâm Ahmad. Beirut: al-Maktab al-Islamî.

Hazm, Ibn. t.th. al-lhkkâm fî Ushûl al-Ahkâm. Mesir: Mathba'ah al-Imâm.

Jashas, Abû Bakar al-. t.th. Ahkam al-Qur'ân. Mesir: Isâ al-Bâbî al-Halabî

Katsir, Ibn. 1984. Tafsîr al-Quran al-'Azhîm. Libanon: Dâr al-Fikr.

Qudamah, Ibn. 1969. al-Mughnî. Kairo: Maktabah al-Qahiriyyah.

Qurthubî, al-. t.th. al-Jamî́ li Ahkâm al-Qur'ân. t.t.: Dâr al-Kitâb al-'Arabiyyah.

Razî, Fakhru al-. t.th. Tafsîr al-Kabîr. Taheran: Dâr al-Kitâb al-'Amaliyyah.

ridlâ, Muhammad Rasyid. t.th. Tafsîr alManâr. Beirut: Dâr al-Ma'rufah.

Suyûthî, Jalâl al-dîn al-. t.th. al-Asybah wa alNazhâir. Semarang: 'Abdul Qadîr alManûr. 
Syâthibî, Abû Ishaq al-. 2002. al-Muwâfaqât fî Ushûl al-Syarî‘ah. Beirut: Dâr al-Kutub al'Arabi.
Zahrah, Muhammad Abû. t.th. Ushûl Fiqh. Beirut: Dâr al-Fikri al-'Arabî

Zuhaylî, Wahbah al-. t.th. al-Dlarûrah alSyar'iyyah. t.t.: Muassasah al-Risâlah. 